\title{
POLITICS AND THE PULPIT: \\ The Rise and Decline of Religion in Nigeria's 2015 \\ Presidential Elections
}

\begin{abstract}
Hakeem Onapajo
Hakeem Onapajo is a Post-doctoral Fellow in the Department of Politics and International Studies, University of Zululand, South Africa

email: onapajokunle@yahoo.com
\end{abstract}

\begin{abstract}
Numerous reports show that Nigeria is one of the most religious countries in the world. Thus, it is not surprising that religion features prominently in the country's elections. The 2015 general election marks another signpost in the interconnection between religion and elections in Nigeria, although with a different pattern. Using an analysis of the 2015 presidential elections, this paper argues that, although religion appeared to play a central role in the pre-election period, it was less significant in the actual voting decision of the electorate on election day. Rather, other factors, especially candidates' profiles and performance records, took precedence over religious and ethnic considerations. This essay concludes that the voting pattern possibly reveals an increasingly sophisticated electorate and a consolidating democracy in Nigeria.
\end{abstract}

Keywords: religion, Muslims, Christians, Nigeria, 2015 presidential elections

\section{INTRODUCTION}

Many studies have proven that Nigerians are amongst the most religious people in the world. A 2015 Global Attitudes Survey by the Pew Research Center revealed that Nigerians are the ninth most religious peoples in the world, with $88 \%$ positive responses from them that 'religion plays a very important role in their lives' (Theodorou 2015). Similarly, a 2005 survey conducted by the BBC World Service found that $85 \%$ of Nigerians 'trusted religious leaders and a similar proportion were willing to give them more power' (Ferrett 2005). With Christianity and Islam as the most widely recognised religions in Nigeria, mosques and churches are a 
common sight on every street throughout the country. The country also has some of the richest and most influential clergies in the world. A Forbes report in 2015 concluded that the five richest pastors in Africa are from Nigeria, with their net worth ranging from USD 10 million to 150 million (www.africaranking.com). It is, therefore, not farfetched to claim that religion takes centre stage in the major spheres of social life, including politics, in this country. Given its effectiveness in identity formation, political mobilisation, and regime legitimacy (Fox \& Sandler 2003), religion has been highly entrenched in Nigerian politics. This is more visible during election seasons as politicians characteristically, but deceptively, make use of religious rhetoric as a powerful instrument to mobilise voters, which has often led to incidents of religious conflict (see Onapajo 2012).

The 2015 general elections provided another arena for religion to be used for electoral gains. The political elites employed religion proficiently as part of their campaign and mobilisation strategies, which was further encouraged by the coincidental climate of perceived religious terrorism orchestrated by Boko Haram fighters who claim to be on a mission to Islamise Nigeria. This phenomenon gave room for many predictions in the media and in academic circles that the electoral process would be both highly religionised and also very violent, and that could contribute to the disintegration of the Nigerian nation. However, to the surprise of many, including the politicians who had actually orchestrated some corrosive plans, the elections ended with credible and remarkable outcomes (Onapajo 2015). This indicates that religion played a less significant role in politics than anticipated.

In light of the background described above, this paper analyses the role of religion in the 2015 presidential elections, with the aim of demonstrating that surprisingly, religion did not play as influential a role as anticipated in the actual voting decision of the electorate. The paper argues that religion was visible in the pre-election period owing to the politico-religious climate which coincided with the elections; yet it cannot be argued convincingly that religion finally played a significant role in the actual voting decision of the electorate.

It should be noted that this study focuses on the presidential election for its analysis. This is owing to the fact that the presidential election is considered to be the most important of the contested positions in the country's elections because of the influential role the president plays in the institutional arrangement of the Nigerian state.

The paper has five sections, excluding this introduction. The first section presents the theoretical and empirical perspectives that show the intersection between religion and electoral politics. On the one hand, the section demonstrates the significance of religion to politics, and on the other hand, it shows the specific importance of religion to elections. The second section gives a historical overview of the role religion has played in Nigeria's electoral politics before the 
2015 elections. The third section analyses the intrigues of the campaign process and the strategic use of religious rhetoric by the contestants and their parties, which is argued as the stage in which religion was actually visible in the electoral process. The fourth section provides an analysis of the results of the election, demonstrating the fact that religion was not very significant in the voting decision of the people. The final section contains the conclusion of this paper, which also analyses the implications of the voting pattern for the electorate and the democratic process in Nigeria.

\section{RELIGION, POLITICS AND ELECTIONS: THEORETICAL AND EMPIRICAL PERSPECTIVES}

Two sets of theoretical literature speak to the connection between religion and elections. They are the literatures on the topics of religion and politics, and of electoral behaviour. The literature on religion and politics is grounded in studies proving the failure of the 'demise of religion' perspective which was popular in the 19th and 20th century theories advocating modernisation and secularisation. In a satirical comment on the increasing irrelevance of the modernisation/ secularisation theories on religion, Gill (2001, p. 119) wrote that: 'If there ever were an award for the most durable, yet outdated, theoretical perspective in the social sciences, secularisation theory would be the winner, or at least a close runner-up.' Similarly, Stark and Finke (2000, p. 79) concluded that: 'After nearly three centuries of utterly failed prophesies and misrepresentations ... it seems time to carry the secularisation doctrine to the graveyard of failed theories, and there to whisper "requiescat in pace".'

Influenced by the rapid trend of religiosity and the increasing influence of religious movements across the world, political scientists who had been influenced by secularisation perspectives began according some importance to religion as a variable in their studies, especially in the post-Cold War era (for example, Marty \& Appleby 1991; Juergesmeyer 1996, Huntington 1993; 1996; Gill 2001). One notable study is that of Samuel Huntington (1993) who argued in his seminal article that religion represents a strong component in the formation of civilisations, and a major factor driving international politics after the Cold War.

The attacks in the United States on 11 September 2001 further motivated research on the role of religion in politics. This produced works confirming that it was wrong for scholars to have jettisoned the role of religion in politics and society (Fox 2001; Philpott 2002). Rather, they point to the fact that religion has been a major factor in politics because it marks a major source of people's world views and, therefore, influences state decisions and is a source of legitimacy or illegitimacy for the government (Fox 2001; Fox \& Sandler 2003). Most importantly, 
it is observed that religion can be instrumental in political mobilisation and collective actions. This is because the activities of religious organisations are often reluctantly restricted by the government. Furthermore, religious organisations do have pre-established platforms and instruments for mobilisation including worship centres, schools, and community activities. Religion remains a major uniting force that can bring together peoples of different ideologies, classes, race, ethnicity, and ages (Fox 2003, p. 567).

Clearly, this shows why religion cannot be ignored as a salient factor in the mobilisation for votes and party support during elections, even in those advanced democracies supposedly built on secularism. This underscores the location of religion in the literature on electoral politics. Early research on voting behaviour has identified religion, alongside other factors such as class, race and ethnicity, as the basis for social cleavages that drive voters' decisions. In their seminal study, Lipset and Rokkan (1967) argued that European politics in the 19th century was driven by social cleavages in which religion was a major factor. As an effective strategy to build and maintain a strong support base, political parties identified themselves with religious groups and interests - Catholic or Protestant, religious or secular (Dalton 1996, p.325). As further cited by Dalton (1996, p.326), Arend Lijphart (1979) observed in his empirical research, which compared the factors of religion, class and language in four democracies, that 'religion was the strongest on voting choice.'

Furthermore, some more recent studies have emphasised the significant (but ignored) role of religious parties such as the Christian Democratic parties with an age-long existence in Europe (Manza \& Wright 2003; Van der Brug, Hobolt, \& Vreese 2009; Kalyvas \& Kersbergen 2010). In the empirical research by Van der Brug et al. (2009, p.1280), it was discovered that in contemporary Europe religion remains 'an important predictor of the vote' and most especially, 'religion is a particularly strong determinant of support for Christian Democratic parties and that Catholics are generally more likely to vote for the centre-right whereas secular citizens are more likely to vote for the centre-left.' Furthermore, their research demonstrated that migration to Europe has a significant impact on rising religiosity in the continent, which may in turn continue to have stronger influence on voting and politics.

In the American elections, numerous studies have also shown the role of religion (Miller \& Wattenburg 1984; Layman 1997; Norris \& Inglehart 2004; Green 2007; Browne 2009). In her historical research, Katie Browne (2009) provided interesting revelations about the influential roles of religious groups including the Catholics, Protestants, Evangelicals and the Jews, as well as the use of religious strategies by candidates, during presidential elections in America since the 19th century. Similarly, Manza and Wright (2003, p.302) argued that historically 'the 
Republicans received very strong support from Episcopalians, Congregationalists, New School Presbyterians, and Methodists; while the Democrats drew support most heavily from Catholics, and less broadly from Lutherans and Unitarians.' Indeed, the increased wave of Christian fundamentalism in the 1960s and 1970s and the rise of groups such as the New Christian Right in the state are significant factors that informed religion-motivated voting in the state.

\section{RELIGION, PARTY POLITICS AND ELECTIONS IN NIGERIA:}

\section{A HISTORICAL REVIEW}

Religion has played a major role right from the early days of elections in Nigeria. This is more apparent in the northern part of the country, given the influential role religion plays in its social system. Religion took a central role in the ideology and membership profile of the first political parties that emerged in the 1950s, following the concession of the colonial government to the nationalists' demands for wider political participation. The three major northern political parties that emerged - the Northern People's Congress (NPC), the Northern Elements Progressive Union (NEPU) and the United Middle Belt Congress (UMBC) displayed a religious character. This was especially true of the Northern People's Congress (NPC), which was the most popular party in the region and was heavily influenced by Islam. According to Dudley (1968, p.143), the party's 'Islamic influence in winning mass support can hardly be underestimated' because the party itself was under the leadership of Muslim leaders including Ahmadu Bello (the Sardauna of Sokoto and founder of Jama'atu Nasril Islam) and Sultan of Sokoto (the de-facto leader of Nigerian Muslims who was the patron of the party). Furthermore, according to Dudley the party was seen as representing a consensus of the Muslim community (Ijma), and refusal to accept the consensus of the community is considered heretical according to Islamic principles. Thus it is not surprising that the party enjoyed tremendous support among the Muslim majority, and for this reason consistently won a majority of the parliamentary seats in the pre- and post-independence elections.

The NEPU, although it was the first political party in northern Nigeria, later became the strongest opposition to the NPC in the Muslim-populated areas of the northern region. Its major aim was the creation of a pro-masses social structure that would challenge the reign of the Fulani aristocrats, thus claiming the identity of a party representing the interest of the Talakawa (the down-trodden) of society. Given that the NPC was associated with the upper strata of the Muslim-dominated society, the NEPU drew its membership from the lower class, mostly constituting the teachers of the local Madrasah and members of the Tijjaniyyah brotherhood - facilitated by the historical conflict between the Qadriyyah (with historical 
connection to the Sultanate of Sokoto under Usman dan Fodio) and Tijjaniyyah (led by the Emir of Kano Alhaji Muhammadu Sanusi) Sufi brotherhoods (Loimeier 1997, p.71). ${ }^{1}$ Indeed, this generated increased intra-religious conflicts and, most especially, the state persecution of prominent Tijjanniyah members. It was in the midst of this crisis that the Emir of Kano was compelled to resign from office and forced into exile in 1963 (Dudley 1968, p.190; pp.216-217).

Another major party opposed to the dominance of the NPC was the United Middle Best Congress (UMBC) whose emergence was conspicuously driven by Christians in the non-Muslim areas, otherwise known as the Middle Belt region. The party was a product of the protest associations and parties created by Christians in the Middle Belt against a perceived Hausa-Fulani Islamic hegemony especially through the instrumentality of the NPC. The UMBC emerged following the merger of the Middle Zone League (MZL) and Middle Belt People's Party (MBPP). These parties derived their sources from the Northern Nigeria Non-Muslim League created with the aid of Christian missions 'to counter Islamic expansionist moves' (Dudley 1968, p. 93). Thus, the UMBC, according to an NPC member, 'is only an ideology infused by the Christian missionaries against the expansion of the Moslems in Northern Nigeria' (cited in Dudley 1968, p. 91). Expectedly, this gave the party some electoral advantage in the Christianpopulated parts of the northern region.

Indeed, the influence of religion in the party formation and voting pattern was not restricted to northern Nigeria. Kukah and Falola (1996, p.87) showed that a Muslim party, the United Muslim Party (UMP), was established in Lagos in 1953 with the aim of contesting elections and to wrest power from the ruling Action Group (AG). However, the party was not successful in its ambition as it was unable to attract established Muslim politicians in the AG to its fold. For this reason, the party could not win any seats in the 1954, 1956 and 1959 elections. In 1957 Muslims formed another political party, the National Muslim League (NML), in protest against the perceived anti-Islamic activities of the AG's government in the western region. Given the NML mission and increasing popularity amongst Muslims in the western region, the AG actually felt threatened by its existence, which was considered capable of reducing the electoral support of the ruling party, particularly in the 1959 general elections. The NML, having changed its name to National Emancipation League (NEL) following criticisms of its use of religion for political mobilisation, entered into an alliance with the NPC. According to

1 It is useful to note that the Qadriyyah and Tijjaniyyah Sufi brotherhoods are the most visible Sufi brotherhoods in Nigeria, whose activities have significant impact on the development of Islam in the country. Qadriyyah had been in existence in northern Nigeria many centuries before the Tijjaniyyah which only surfaced in the 19th century. The leadership of the Sokoto Caliphate was affiliated with Qadriyyah, while the Emirs and scholars opposed to the status quo under the Caliphate joined the Tijjaniyyah. For a detailed analysis on the conflict between the two brotherhoods, see Loimeier, R. (1997). 
Kukah and Falola (1996, p.90), even though the party was unable to neutralise the dominance of the AG, given its failure in the 1959 elections, it was able to represent a formidable opposition to Awolowo's AG in the western region.

In the Second Republic religion did not disappear from electoral politics. This was despite attempts by the government to discourage religion-driven parties with the constitutional provision that no political party could carry the identity of any ethnic or religious groups. It should be recalled that the Second Republic was preceded by an intense debate over the inclusion of a provision for a Federal Sharia Court of Appeal in the draft constitution at Constitutional Assembly in 1977/78, which culminated in major rivalry between Muslims and Christians. Clearly, this environment created an avenue for the manipulation of religious texts and for the faithful to garner votes. The most popular parties, including the National People's Party (NPN), Unity Party of Nigeria (UPN), People's Redemption Party (PRP), and the Nigeria's People's Party (NPP), were associated with either Christianity or Islam. For example, the NPN, being a duplication of the old NPC, was seen as a product of the aristocratic Fulani Muslims in the north because of the nature of its leadership and popular base. The PRP was associated with the Tijjaniyyah brotherhood given its closeness to the old NEPU, while it gained its electoral strength in Kano and Kaduna with a considerably higher presence of the brotherhood. The UPN and NPP were perceived more as Christian parties owing to their leadership and areas of influence (Oloyede 1987). It should be noted, however, that in the western region there were notable Muslims in the UPN and also Christians in the NPN, as the Yoruba are known for a liberal approach towards both Christianity and Islam (see Laitin 1986). Yet it was still a prevalent perception in some sections among the Yoruba that UPN was antiIslam. For example, Muslim members of the NPN in Oyo State were proficient at using campaign slangs and songs to discourage Muslims from voting for the UPN, following their classification of that party as leading to Jahannum (hell-fire) (Oloyede 1987, p.83). In the eastern region, Eze (2009) also argued that the church campaigned vigorously for NPP which greatly contributed to the party's success in the region.

In the Third Republic, research indicates that there was some religious dimension to the political process. This was despite the popular belief that religion had been insignificant in the 1993 presidential elections following the MuslimMuslim ticket (Muslim presidential and vice-presidential candidates) advanced by the Social Democratic Party (SDP), which was massively supported at the ballot box across the country. It was reported that Christians under the banner of the Christian Association of Nigeria (CAN) in the north actually threatened to boycott the elections if the candidates presented by the SDP and National Republican Convention (NRC) were Muslims (Osaghae 1998 p.237). For this reason, some 
Christian presidential aspirants (including S.L Slifu, a former Secretary-General of the northern branch of CAN, and Jerry Gana) were encouraged to join the race chiefly to challenge the Muslim aspirants. However, they were unable to succeed at the primaries (Rufai 2011, p.176). Furthermore, after the military regime annulled the presidential election won by Moshood Abiola, it was reported that Yoruba Muslims actually lobbied the Hausa-Fulani Muslims requesting the Sultan of Sokoto to use the influence of his office to condemn the annulment (Suberu 1997, p.420). Rather than condemn the act, the Sultan, Ibrahim Dasuki, only urged Abiola to 'accept the annulment as "an act of God"' (Rufai 2011, p.176).

The transition programme initiated by General Abdulsalami Abubakar in 1998 kick-started a journey into the Fourth Republic. The new republic, just like the previous ones, has not been devoid of religion during elections. Clearly, this can be meaningfully connected to the politics around the emergence of Olusegun Obasanjo as President in 1999. The emergence of Obasanjo, a southern Christian, was the outcome of an agreement amongst the political elite, spearheaded by the northern military leaders and influential political elite. This was to pacify the Yoruba after the injustice done to Abiola over the annulment of the 1993 presidential elections and his subsequent incarceration, which led to his death in prison in 1998. Shortly after Obasanjo assumed power, the northern Muslim elite suspected attempts to Christianise the presidency by his Christian aides and certain groups close to him. This group of people, dubbed the 'Theocratic Class' by Ebenezer Obadare (2006), was driven by the increasingly influential Pentecostal Church. They gave President Obasanjo the image of a 'born-again' president and defined him as 'a personal embodiment of divine response to their prayers and prophecies for the nation' (Obadare 2006, p. 670). According to some, the fear nurtured by the northern Muslims over this development was partly responsible for the introduction of the Sharia system in twelve states of the Muslim-majority areas in the north with the aim of countering the apparent moves of an emergent Christian power bloc (Akinyele 2001).

The northern elites further advanced vehement moves to wrest power from the southern Christians. This move reached a crescendo after the sudden death of Umaru Musa Yar'Adua in 2010 who was unable to complete his term as the president. His death necessitated the succession of his southern Christian vicepresident, Goodluck Jonathan, as the president in 2010, in accordance with the Nigerian constitution. Jonathan later ran for presidential office and won in 2011. It is instructive that Jonathan's decision to stand for the office of president was met with total resistance from the northern politicians who saw the move as a violation of an existing zoning formula in the People's Democratic Party (PDP), which was supposed to favour a northern candidate. It was also more upsetting for the northern politicians that Jonathan was strongly supported by former President 
Obasanjo, who had gathered enough power to exert tremendous influence in the PDP and in the country. Therefore, this situation was used as a reason to mobilise Muslims in the north against Jonathan's candidature in the 2011 elections after he defeated Atiku Abubakar, who was seemingly the 'Northern Consensus Candidate' at the PDP primaries (Onapajo 2012).

The religionisation of the 2011 electoral process was further strengthened by the emergence of Muhammadu Buhari as the presidential candidate of the Congress for Progressive Change (CPC). Buhari, who had been labelled a Muslim fundamentalist by his opponents because of his positive remarks on the Sharia legal system and his Islamic devotion, enjoyed obsessive following by Muslim youth and clerics, not only in the north but also in the southern region. Therefore, ensuring the success of his presidential ambition was considered a religious duty. To that extent, any act of opposition to Buhari's candidature by a Muslim was even considered heretical by some Muslim leaders and groups (Onapajo 2012).

Goodluck Jonathan also created for himself the image of an oppressed Christian who needed the support of his brethren to win the presidential election. He regularly attended church programmes in order to identify himself with the large Christian population and mobilise votes to realise his ambition. The most notable was his visit in December 2010 to an annual event of the Redeemed Christian (Pentecostal) Church, 'The Holy Ghost Night', which provides an avenue for one of the largest Christian gatherings in Nigeria. He knelt before the church's highly influential pastor, Pastor Enoch Adeboye, ostensibly to pray for the nation, but in fact to advance his political ambition. Some other church pastors also conspicuously campaigned for him in their churches. For example, it was reported that a Lagos-based Pentecostal pastor, Paul Adefarasin, of the House on the Rock Church, urged his followers to unanimously support a Christian presidential candidate in the 2011 elections (see Onapajo 2012).

Therefore, the 2011 presidential election seemed to be a major contest between a Christian and Muslim candidate. The pattern of voting clearly confirmed this assertion as it was apparently characterised by the Christian-Muslim divide in the country. In the Christian-dominated areas of the south and the Middle Belt, Jonathan had a landslide victory over Buhari. On the other hand, Buhari was overwhelmingly voted for in the Muslim-dominated areas consisting of twelve states: Sokoto, Zamfara, Niger, Kano, Kebbi, Katsina, Bauchi, Kaduna, Jigawa, Borno, Gombe and Yobe. Though the result was controversial, Jonathan garnered a total 22495187 (58.89\%) votes in 23 states of the federation over Buhari's 12214 $853(31.98 \%)$ which earned him victory (http://www.inecnigeria.org). Violent protests against this election outcome by youths in the north resulted in the deaths of about 800 people as well as arson attacks on worship centres (International Crisis Group, 2011). 


\section{RELIGION IN THE 2015 PRESIDENTIAL ELECTIONS}

Electoral politics of 2015 were clearly an extension of the politics of the 2011 elections. The loss of that contest to Goodluck Jonathan reinforced the determination of the northern Muslims to ensure the emergence of someone from their community as the president in the 2015 elections. This agenda was easily adopted by other Muslims across the country as Jonathan's government was increasingly seen as biased towards his Christian brethren. This is judged by his closeness to notable Christian leaders, especially Pastor Ayo Oritsejafor (the President of the CAN), who were regularly visible at the presidential villa and also wielded much political influence. Muslims also felt aggrieved by some policies of the government which were seen to be marginalising them. A notable example was their disenchantment with the composition of the National Political Reform Conference held in 2014, which had an unbalanced number of Muslim representatives in comparison with their Christian counterparts. This triggered a protest visit by the Muslim community, led by the Sultan of Sokoto, Alhaji Muhammadu Sa'ad Abubakar, to President Jonathan in March 2014 to lodge a formal complaint about the situation (Premium Times, 26 March 2014). Although Jonathan assuaged their feelings, denying any deliberate attempt to marginalise the community and promising that the imbalance would be corrected, the Muslim community felt deceived and aggrieved that no substantial effort was made by the government to address their concerns. This is clear in the following statement by Ishaq Oloyede, the Secretary-General of the National Supreme Council of Islamic Affairs (NSCIA), that:

The Muslim community met with the then president [Jonathan]. He saw that the composition was flawed. He admitted that it was an error and promised heaven and earth. He never did anything to rectify the error.

(Akinyemi 2015)

Boko Haram violence is another prominent issue that has contributed to the religionisation of the 2015 electoral politics. This is because violence takes the form of religious terrorism when the Boko Haram group claims to be on a mission to Islamise Nigeria, based on its own interpretation of Islam. A major consequence of the Boko Haram attacks, therefore, is the deterioration of an already bitter Christian-Muslim relationship in the country. On the one hand, Christians perceive the Boko Haram insurgents as a sort of 'Muslim army' that aims to actualise a long-term Muslim agenda to Islamise Nigeria. In addition, some Christian leaders alleged that the entire incidence of Boko Haram was actually orchestrated by northern Muslims in order to force a Christian president out of 
power against the backdrop of the 2011 elections. Thus, they consistently claim that Christians and churches are the main targets of the deadly group (Onapajo \& Usman 2015).

On the other hand, a popular view within the Muslim community was that Boko Haram was a plot by Christians to tarnish the image of Islam and of the Muslim elites who were opposed to Jonathan's presidency. They claimed that many incidents of Boko Haram attacks had been discovered to be connected to Christians and their leadership. Furthermore, some Muslims claimed that there was a 'Federal Government Boko Haram', suggesting that Jonathan's presidency was behind some Boko Haram-related attacks aimed at preventing voting in the largely Muslim-dominated North East, in order to decimate the electoral chances of the Muslim candidate. Indeed, this altercation nearly pushed the country to the brink of a religious war as the leadership of both religious groups threatened reprisal attacks against each other (see Onapajo \& Usman, 2015).

Clearly, this political climate created a major religious division which was useful to the political elite in preparation for the elections. This made religion a very useful tool in the hands of the political elites in the electoral process. The following sub-sections provide an analysis of how the political elite went about using religion as an instrument for voter mobilisation in the pre-election period.

\section{CLAIMS OF RELIGIOUS PARTIES}

The Nigerian constitution (1999) categorically disallows religion-based or ethnicbased parties, in order to promote national unity. While there is no evidence to show that any of the major political parties involved in the presidential contest - the People's Democratic Party (PDP) and All Progressives' Congress (APC) are affiliated to any religion, politicians used the strategy of associating their opponent's party with a particular religious group with the aim of making it unpopular and thereby attracting sympathy votes from targeted religious groups and even secular voters. This was adeptly used by the PDP against the APC in the campaign process. On several occasions the PDP alleged that the APC was an Islamist party founded in the same fashion as the Muslim Brotherhood of Egypt, with links to other international Islamist groups, with the ultimate intention of Islamising Nigeria. For example, Olisa Metuh, the National Publicity Secretary of the PDP, stated that:

... it is shocking that the APC would attempt to hoodwink Nigerians even in the face of incontrovertible facts exposing its religious inclinations and plots to divide the nation along religious lines... the revelations by an Islamic cleric, Ambassador Yusuf Garba and 
the Religious Equity Promotion Council, REPC, that APC seeks to impose an agenda like the Egypt Muslim Brotherhood remains a fact that cannot be brushed aside.

(Umoru \& Akinrefon 2014)

Furthermore, the APC was accused of having connections with the Boko Haram group in order to destabilise Jonathan's administration. This claim was made by Femi Fani-Kayode who was the Director of Media and Publicity in Goodluck Jonathan's re-election campaign team, and who wrote acerbically on his Facebook page that: 'The APC is the political wing of Boko Haram and Boko Haram is the military wing of the APC, Say NO to the Haramite murderers and barbarians' (Vanguard 6 August 2014).

In the northern region it was easy to discredit the PDP as a Christian party, given the accumulated grievances of the people against Jonathan. Thus, the $\mathrm{APC}$ members in the region exploited the situation to project the PDP as a party promoting the interest of a Christian candidate. Sule Lamido, a PDP governor in Jigawa State, alluded to this while alleging that the presidential candidate of the APC, Muhammadu Buhari, usually identified himself with the Muslim community at campaigns in northern Nigeria, but he preached the message of a united Nigeria in the south. He therefore lamented: 'Why then are our people [PDP members] vilified and maligned because they refuse to vote for a Muslim as their president and have opted for a Christian?' (Top News 2014). Interestingly, the vice-president and the running mate of President Jonathan under the PDP, in a bid to mobilise votes for his party in the north, claimed that the APC should rather be viewed as a Christian party because 'their chairman is a Christian, their Campaign Director General is a Christian and the Vice President (candidate) is a pastor' while in his party, 'Our chairman is a Muslim, the Director General of our campaign is a Muslim likewise. I, Namadina Sambo, am Muslim. It is only our presidential candidate that is a Christian' (Iyatse 2015).

\section{RELIGIOUS IDENTITY OF THE PRESIDENTIAL CANDIDATES}

The politics around the religious profile of the major candidates were also central to the politics around the elections. Goodluck Ebele Jonathan is an Anglican Christian from the Ijaw ethnic group of the Niger Delta, a region which had the earliest contact with Christianity in Nigeria, and a reason why this religion is most popular among its peoples. The translation of Jonathan's traditional name 'Ebele' means 'God's wish' (BBC, 2015). Jonathan, since his assumption of the presidential office in 2010, increasingly projected himself as a good Christian, a regular church-goer, and for which he was immediately accepted as a pious 
brother by the large Christian community. Shortly after his emergence as the president in 2010, Reverend Father Matthew Kukah, the Bishop of the Sokoto Catholic Diocese, was one of the first Christian leaders to give a spiritual definition to the process leading to his presidency. He ascribed it to a 'monumental act of divine epiphany' and that his 'rise has defied any logic and anyone who attempts to explain it is tempting the gods' (Kukah 2010).

To further show his commitment to the Christian faith, Jonathan took upon himself the duty of embarking on a regular pilgrimage to Jerusalem, usually with a large entourage. He did not only choose notable Christian leaders as close friends, he was also very generous to the community. Pastor Tunde Bakare, the founder and presiding pastor of the Latter Rain Ministries and a social critic, revealed in an interview that 'Christian leaders benefitted tremendously from his (Jonathan's) administration in terms of licenses and waivers' (Jaafar 2015). His generosity to the community was not restricted to granting waivers and licenses, as he also used his office to facilitate huge cash donations for church projects. A typical example was the fundraising organised for the St. Stephen's Anglican Deanery and Youth Development Centre of his hometown church in Otuoke, Bayelsa State. At the programme launch attended by Jonathan and his friends - including incumbent governors of his party, government contractors and bank executives - the sum of 6 billion Naira was raised for the project (Ehikioya 2013). Clearly, these credentials are enough for him to win the Christian vote as he did in 2011. However, this calculation was thwarted by the emergence of a seemingly stronger Christian, Yemi Osinbajo, a pastor at the enormously influential Redeemed Church, who was the vice-presidential running mate of the opposition candidate. I shall return to this shortly.

While the Christian votes seemed guaranteed, the major challenge for Jonathan and the PDP was the selection of a running mate who would be acceptable to the largely Muslim population in the north. Apparently, Namadi Sambo, a non-Fulani northern Muslim from Zaria, incumbent vice-president and former governor of Kaduna State, did not possess that quality in the face of a strong Fulani Muslim opposition candidate - Muhammadu Buhari. This, especially, is against the backdrop of his outright loss to the same candidate (Buhari) in his own voting constituency in 2011. His property was also the target of destruction by protesting youth in Kaduna after Buhari lost the election to Jonathan in 2011. It is for this reason that some PDP chiefs initially planned to drop Sambo as the vice-presidential candidate for the 2015 elections. Some other relatively acceptable candidates were considered as his replacement, including Sule Lamido (then governor of Jigawa State) and Ibrahim Shema (then governor of Katsina State) (Ahaoma \& Ibraheem 2014). Perhaps because he feared the 
presidential ambition of the aforementioned candidates, Jonathan retained Sambo as his running mate, despite his lack of popularity in the northern region and among the Muslim community.

APC presidential candidate Muhammadu Buhari's devoted Islamic life and his seemingly favourable disposition towards the Sharia system was seen by his opponents as a political flaw that could weaken his chances. Buhari's opponents in the PDP accused him of being the brain behind the Boko Haram violence given the statement he made in 2012 that: 'God willing, by 2015, something will happen...if what happened in 2011 should again happen in 2015, by the grace of God, the dog and the baboon would all be soaked in blood' (Vanguard 15 May 2012). This claim is further substantiated after some self-acclaimed Boko Haram leaders in 2012 named Buhari as one of the individuals they respect and who could mediate on their behalf with the government. Although he rejected the offer and proved he had no connection with the group, the PDP ensured that this was used to exploit against Buhari's candidacy. For example, Fani-Kayode of the PDP wrote that:

... some people still say they want Buhari as President? A man who said, only last year, that 'an attack on Boko Haram is an attack on the north'? A man who said, in 2001, that he wants to 'spread sharia throughout the federation'? A man who said, in 2001, that 'Muslims should only vote for Muslims'? A man who said, in 2001, that 'why should Christians be concerned when Muslims cut off their limbs under sharia'? A man who said, in 2001, that 'after all the limbs that are being cut off are Muslim ones and not Christians, so why should the Christians bother about it'? ...This is the man that some Nigerians are clamouring for to be their President? May God open their eyes and protect them from themselves

(Godwin 2014).

Having realised the potential of the strategy consistently used against Buhari, his party members considered it more strategic to select a strong Christian personality as his running mate for the elections. Buhari also did this in 2011 when he campaigned for the presidency with Pastor Bakare as his running mate on the CPC platform, which was unsuccessful given the weak structure of the party in the southern region. This strategy was adopted as a good option for the 2015 elections, judging by the rising tension generated in the country following speculations that the APC was ready to stage a Muslim-only ticket for the presidential and 
vice-presidential positions. Yemi Osinbajo, a pastor in a popular Lagos branch of the Redeemed Church and an associate of Bola Tinubu (the National Leader of the APC), was therefore appointed as a suitable vice-presidential candidate.

The emergence of Osinbajo immediately disrupted the plans of Jonathan and his party. This is because, besides being a prominent member of the Redeemed Church, Osinbajo was also very close to the founder and general pastor of the church, Pastor Adeboye. This in turn suggests that the large number of votes from the Redeemed Church, which has an estimated five million members and about 14,000 branches across the world (Miller 2010), would most likely go to the APC because of Osinbajo. Furthermore, the fact that Pastor Osinbajo appears more devoted and disciplined as a Christian would attract him more Christian voters than Jonathan. A report confirmed that, after the nomination of Osinbajo, Jonathan complained to some Pentecostal pastors that 'everything was okay until APC picked Osinbajo' (Sahara Reporters 19 January 2015).

\section{MOBILISATION AND CAMPAIGN STRATEGIES}

The electoral process was characterised by the contestants and their parties meeting with religious leaders, ostensibly in order to use these leaders to favourably influence their followers' votes. For example, following several overt and covert meetings Jonathan had with the Christian leadership, Rotimi Amaechi, then governor of Rivers State and also director general of the APC presidential campaign, alleged that Jonathan gave Christian leaders, through the CAN, the sum of 6 billion Naira to use for their churches to gather votes and also discredit the APC as pursuing an Islamisation agenda. In another allegation, which further substantiated Ameachi's claim, the Director of the Voice of Northern Christian Movement, Pastor Kallamu Musa Ali Dikwa, alleged that:

Actually President Jonathan is using CAN president, Pastor Ayo Oristejafor, and it was the CAN president that collected the monies and shared N3 million to CAN executives in each state. And some Pentecostal Bishop including Bishop Oyedepo also collected his share. Actually, the money is not N6b, it is N7b.

(Joseph \& Benjamin, 2015)

Therefore, it was not surprising when Jonathan announced some months before the elections that 'we have decided that from now onward, until I leave the State House, every last Sunday of the month, I will go to different churches,' which was later termed the 'presidential church tour' in the media (Nzemeke 2014). Obviously, this was a tactic of using the pulpit to campaign and persuade the 
Christian voters to vote for him. This motive saw him visit notable churches across the country, especially in Lagos and Abuja, before the commencement of elections on 28 March 2015.

Similar attempts were made to mobilise the leadership of the Muslim community to support his re-election. This was not totally successful as there were strong indications that the community was determined not to support his re-election given the perceived mistreatment of Muslims under his administration. Thus, all entreaties to the Muslim community in different guises by Jonathan and his party in order to secure its cooperation were rejected. For instance, Ishaq Akintola, the director of Muslim Rights Concern (MURIC), while querying the motive behind any meeting with Jonathan at the auspicious time of the elections, remarked that:

President Jonathan neglected and marginalised us in the past. Why is it now that he wants to meet us? If he wants to meet us, he should wait till after the election, not now. We don't want his dollars.

(The News 2015)

However, some selected Muslim leaders in the South West, including Edo and Delta States, held a meeting on 17 March 2015 with the vice-president, Namadi Sambo, and a number of PDP members in Akure, Ondo State, where they endorsed Jonathan's candidacy. However, this meeting and endorsement were swiftly disowned by the larger Muslim community in the South West under the umbrella of the Muslim Ummah of South West Nigeria (MUSWEN), which declared that: 'There is no prominent Imam from the Southwest at the meeting because we all agreed not to be part of such a clandestine move' (Adebanjo \& Akeredolu 2015).

On the part of the APC, the candidate and his campaign team held some consultations with notable pastors, excluding the CAN whose leadership had already pitched its tent with the PDP's candidate. Buhari's strategists saw the meetings as important in order to repudiate the perception created by his opponents against him as a Muslim fanatic. In January 2015, the pictures of Buhari attending a Christian event where Pastor Adeboye was the presiding pastor, occupied the social media, ostensibly to indicate his religious liberalism. On 10 February 2015, Buhari also had a meeting with Catholic bishops where he emphasised that he 'will not condone any initiative that seeks to promote one religion over the other' (Premium Times 11 February 2015). About the same time some Christian leaders met under the banner of Northern Christian Leaders' Eagle-Eyes Forum in Abujato declare their support for the Buhari-Osinbajo ticket.

In a discussion with the General-Secretary of the National Council of Muslim Youths Organisations (NACOMYO) Lagos State branch, it was understood that 
Buhari had decided not to follow the approach of Jonathan concerning the Muslim community. Therefore, Buhari significantly reduced his meetings with the community at the close of the elections in order to weaken the negative image of 'Muslim fanatic' already given to him by his opponents, and also to prevent the perception that he would be biased towards his religion when elected into office. However, according to my interviewee, many Muslim organisations committed themselves to the success of Buhari at the presidential elections not only because he is a Muslim, but also because of Jonathan's outright display of 'hatred' towards Muslims in his administration (personal communication, 2015).

\section{VOTING AND THE DECLINE OF RELIGION}

Despite the pervasiveness of religion in this pre-election period, one cannot successfully argue that religion was a major factor in the voting pattern. The Muslim-dominated northern areas in the North East and North West did vote massively for Buhari, while the largely Christian areas in the South East and South South voted predominantly for Jonathan, and this has something of an ethnic dimension (see Table 2). The pattern of voting in two major geo-political zones with a large Christian population, North Central and South West, is instructive for analysis here. In the North Central, which is mostly composed of the northern Christian-populated states - Benue, Plateau, Nasarawa and Kogi States - the APC candidate beat the PDP candidate by over 25\%. This is unexpected in those areas especially when considering the votes Jonathan (as a Christian candidate) recorded there in the 2011 elections (see Table 1). In addition, when considering the results at state levels it is striking that in Benue and Kogi States, Buhari earned more votes than Jonathan by $18.8 \%$ and $43.3 \%$ respectively. In some other predominantly Christian-populated states, including Plateau and Taraba where Jonathan recorded more votes, the margin was surprisingly narrow (22\% and $16 \%$ respectively). Also in the South West, with a seemingly mixed population of Muslims and Christians, there was a margin of $25.1 \%$ in favour of the APC candidate. With this result, there is reason to suggest that factors other than religion played significant roles in the voting choice of the people.

Table 1

Result of the 2015 Presidential Election According to Geo-Political Zones

\begin{tabular}{|l|c|c|}
\hline Zone & PDP (Jonathan) & CPC (Buhari) \\
\hline North Central & 3123126 & 1612999 \\
\hline North East & 1832622 & 3624919 \\
\hline
\end{tabular}




\begin{tabular}{|l|c|c|}
\hline North West & 3395724 & 6453437 \\
\hline South East & 6118608 & 49978 \\
\hline South South & 4985246 & 20335 \\
\hline South West & 2786417 & 321609 \\
\hline Total & 22495187 & 12214853 \\
\hline
\end{tabular}

Source: Nigeria Muse 19 April 2011

Table 2

\section{Result of the 2015 Presidential Election According to Geo-Political Zones}

\begin{tabular}{|l|l|l|}
\hline Zone & APC (Buhari) & PDP (Jonathan) \\
\hline North Central & 2411013 & 1874638 \\
\hline North East & 2848678 & 796588 \\
\hline North West & 7115199 & 1339709 \\
\hline South East & 198778 & 2464906 \\
\hline South South & 418590 & 4714725 \\
\hline South West & 2433193 & 1821399 \\
\hline Total & 15425451 & 13011965 \\
\hline
\end{tabular}

Source: Independent National Electoral Commission Website (accessed 22 October 2015)

Two reasons may account for this pattern of voting which saw a reduced role of religion:

Firstly, pre-election surveys conducted in some states that produced surprising outcomes, as indicated above, clearly show that despite attempts at politicising their worship centres, voters' decisions were based on the performance records of the presidential candidates, especially on issues concerning security, corruption, and employment. For example, a number of Christians in Plateau State interviewed in a BBC report suggested that the religious affiliation of the candidate would not be primary in their voting decisions; rather their credibility would be a major determinant. According to a Christian voter, 'If the Christian leader does not have what it takes to provide good leadership, I will not vote for him merely because he is a Christian' (Ross 2015). Another respondent stated that '... the way things are going people are beginning to downplay the role of religion in deciding who you vote. I hear people talking a lot about credibility' (Ross 2015).

It should be noted that the Jonathan administration in particular lost its 
popularity following its poor management of Boko Haram violence and other related ethno-religious violence in the northern region, which significantly affected his fellow Christians. On the other hand, there were increased expectations that Buhari, as a retired general in the Nigerian Army with a record of dealing with similar terrorist groups in the 1980 s as a military head-of-state, ${ }^{2}$ would handle the situation better. Furthermore, Jonathan lost credibility in the face of a deluge of corruption allegations against his cabinet members, about which he was passive. A good example is the allegation made by the Governor of the Central Bank of Nigeria, Sanusi Lamido Sanusi, that a sum of USD 20 billion from the oil revenue account went missing on the watch of the Minister of Petroleum, Diezani Alison-Madueke. Rather than institute a convincing investigation into the allegation, President Jonathan suspended the whistle-blower (Sanusi Lamido) on some fabricated charges. On the other hand, Buhari was seen not only as being personally free of corruption but also as an anti-corruption crusader because of his record as the military head of state between 1983 and 1985, when he significantly addressed the problem of corruption and all forms of indiscipline in the country through the policy of 'War Against Indiscipline' (WAI).

Secondly, the campaign strategy of the PDP against the APC candidate based on his personality and religion was apparently counter-productive, as it ended up pitting one religion against the other. This strategy was considered inflammatory as it could have pushed the country to the point of a religious war. This position is also admitted by the leadership of the PDP after it was accused by the campaign team of causing Jonathan's failure at the elections. The Publicity Secretary of the party responded that:

We (National Working Committee) did not lead the party to failure. We were not involved in the campaigns and our advice was ignored ... in 2003, President Obasanjo ran an election against OdumegwuOjukwu in the South-East. In 2007, Yar'Adua ran election against Ojukwu. I can tell you, if PDP had engaged in name calling or abused Ojukwu in any way, PDP would have lost the elections in the South-East.

(Umoru 2015)

This shows that Nigerian voters are gradually becoming more sophisticated. With the outcome of the 2015 presidential elections, one can argue that the inclination

2 Muhammadu Buhari was Nigeria's Military Head-of-State from December 311983 to August 271985. His administration confronted the Maitatsine sect which engaged in religious insurgency in some cities of northern Nigeria. In addition, he was also one of the major military officers who fought in the Biafran civil war between 1967-1970. 
to vote for visceral reasons may be on the decline. More voters displayed their preference for the performance capacity of the presidential candidates, rather than their religious or ethnic backgrounds. In a liberal democracy, a quality and rational voter is certainly a useful criterion for the development of democracy. This observation reflects a research finding based on the case study of Ghana indicating the emergence of a 'rational voter in Africa' who 'are consciously or unconsciously placing a significant premium on their sense of the economy and of whether the government's policies have helped or hurt most people' (Lindberg 2012, p.10). Although this does not necessarily indicate the death of identity factors in elections, it suggests that incumbents and parties will pay more attention to delivering on their mandate in order to be re-elected, rather than having an easy path into office courtesy of their religion or ethnicity.

\section{CONCLUSION}

Nigeria's status as one of the most religious countries in the world ensures that the connection between its religion and politics is relevant to the literature on this subject. The involvement of religion in Nigerian politics relates to its use as an instrument for mobilising votes in elections. As shown in this paper, the history of Nigeria is replete with the invocation of religious sentiments for electoral gains. Clearly, the 2015 presidential elections provide another significant example of how the political elite attempt to manipulate religion and influence the faithful to gather votes and win elections. As such, this study of the politics around the elections is about how the faithful were mobilised at their places of worship in order to win the elections. This was clearly manifested in the campaign strategies of the major contestants for presidential office. Furthermore, by analysing the voting patterns, this paper demonstrates that despite this strategy, religious sentiments had minimal effect on the voting choice of the electorate. The voters instead made their choice based on the performance records of the presidential candidates. This has positive implications for democratic development in Nigeria. It shows that the voters are indeed becoming more rational and less sentimental at the polling station, despite the manipulations of political elites.

\section{- REFERENCES -}

Adebanjo, T \& Akeredolu, L 2015, 'Rumpus in Southwest as Muslims back Jonathan', The Nation, 19 March. Available at: $<\mathrm{http}$ / / thenationonlineng. net/rumpus-in-southwest-as-muslims-back-jonathan/> (19 March 2015).

African Ranking, 2015, 'Richest pastors in Africa', http://www.africaranking. com/ richest-pastors-in-africa/ (20 September 2015). 
Ahaoma, K \& Ibraheem, M 2014, '2015 running mate: Jonathan's dilemma', New Telegraph, 26 October, p. 5.

Akinyele, RT 2001, 'Ethnic militancy and national stability in Nigeria: A case study of the Oodua People's Congress', African Affairs vol.100, no. 401, pp.623-640. Akinyemi, K 2015, 'How we rejected Jonathan's temptations during 2015 elections - Prof Oloyede'. Available at http:/ / www.dailytrust.com.ng/sunday/index. php/ politics / 21277-how-we-rejected-jonathan-s-temptations-during-2015elections-prof-oloyede\#UHIUQFEXFAU801Ze (16 September 2015).

BBC 2015, 'Nigeria's Goodluck Jonathan, profile of a defeated president'. Available at: <http://www.bbc.com/news/world-africa-12192152> (15 September 2015).

Browne, K 2009, ‘Religion and presidential elections: From accusations of Atheism to proclamations of the Born-Again', Chrestomathy, vol.8, pp. 30-44.

Dalton, RJ 1996, 'Political cleavages, issues, and electoral change,' in LeDuc, L. Niemi, RG and Norris P (eds.), Comparing democracies: elections and voting in global perspective, Sage Publications, Thousand Oaks, CA.

Dudley, BJ 1968, Parties and politics in Northern Nigeria, Frank Cass and Company Limited, London.

Ehikioya, A 2013, 'Outrage over N6bn donation to Jonathan's hometown church', The Nation, 17 March. Available at: <http:/ / thenationonlineng.net/outrageover-n6bn-donation-to-jonathans-hometown-church/> (10 September 2015).

Eze, J 2009, 'The church and presidential democracy: Political party elections in Igboland, 1979-2003', International Journal of Research in Arts and Social Sciences, vol.1, pp.160-169.

Ferret, G 2005, 'Africans trust religious leaders', BBC 14 September. Available at: $<$ http:/ / news.bbc.co.uk/2/hi/africa / 4246754.stm> (20 December 2015)

Fox, J 2001, 'Religion: An oft overlooked element of international studies', International Studies Review, vol.3, pp. 53-73.

Fox, J \& Sandler, S 2003, ‘Quantifying religion: Toward building more effective ways of measuring religious influence on state-level behaviour', Journal of Church and State, vol. 45, no.2, pp. 559-588.

Gill, A 2001, 'Religion and comparative politics', Annual Review of Political Science vol.4, pp. 11-38.

Green, JC 2007, The faith factor: how religion influences American Elections, Praeger, New York.

Godwin, A 2014, 'I stand with Jonathan, Buhari can never rule Nigeria - FaniKayode', Daily Post, 12 December. Available at: <http://dailypost. $\mathrm{ng} / 2014 / 12 / 12$ / stand-jonathan-buhari-can-never-rule-nigeria-fanikayode/> (12 September 2015).

Huntington, SP 1996, The clash of civilizations and the remaking of world order, Simon \& Schuster, New York. 
Huntington, SP 1993, 'The clash of civilizations?', Foreign Affairs, vol.72, no.3, pp. 22-49.

International Crisis Group 2011, Lessons from Nigeria's 2011 elections, ICG, Brussels. Iyatse, G 2015, 'PDP has more Muslims than APC - Sambo', Punch, 5 February. Jafaar, J 2015, 'What I benefited from Jonathan - Pastor Bakare', Premium Times, 11 September. Available at: <http:/ / www.premiumtimesng.com/news/ headlines / 189873-what-i-benefited-from-jonathan-pastor-bakare.html (11 September 2015)

Joseph, M \& Benjamin, I 2015, ‘Jonathan gave CAN N7bn not N6bn, Pastor Dikwa alleges', Leadership, 20 February. Available at: <http://leadership.ng/ news / 412848/ jonathan-gave-can-n7bn-not-n6bn-pastor-dikwa-alleges> (20 February 2015).

Juergensmeyer, M 1996, 'The worldwide rise of religious nationalism', Journal of International Affairs vol.50, no.1, pp. 1-20.

Kalyvas, SN \& Van, KK (2010) 'Christian democracy', Annual Review of Political Science vol.13, pp. 183-209.

Kukah, MH 2010, 'The patience of Jonathan', The Will, 25 May. Available at: <http: / / www.thenigerianvoice.com/news / 24972 / 1/ the-patience-ofjonathan.html> (20 September 2015).

Kukah, MH \& Falola, T 1996, Religious militancy and self-assertion: Islam and politics in Nigeria, Avebury \& Ashgate Publishing Limited, Hants \& Vermont.

Laitin, DD 1986, Hegemony and culture: politics and religious change among the Yoruba, University of Chicago Press, Chicago.

Layman, GC 1997, 'Religion and political behavior in the United States: The impact of beliefs, affiliations, and commitment from 1980 to 1994', The Public Opinion Quarterly, vol. 61, no.2, pp. 288-316.

Lijphart, A 1979, 'Religious vs. linguistic vs. class voting: the "crucial experiment" of comparing Belgium, Canada, South Africa, and Switzerland', American Political Science Review, vol. 73, no.2, pp. 442-458.

Lindberg, SI 2013, 'Have the cake and eat it: the rational voter in Africa', Party Politics, vol. 19, no.6, pp. 945-961.

Lipset, SM \& Rokkan, S 1967, 'Cleavage structures, party systems, and voter alignments: an introduction' in SM Lipset \& S Rokkan (eds.), Party systems and voter alignments: cross-national perspectives, Free Press, New York.

Loimeier, R 1997, Islamic reform and political change in northern Nigeria, Northwestern University Press, Evanston, Illinois.

Manza, J \& Wright, N 2003, 'Religion and political behavior', in M Dillon (ed), Handbook of the sociology of religion, Cambridge University Press, Cambridge.

Marty, ME and Appleby, RS 1991, Fundamentalisms observed, University Chicago Press, Chicago. 
Miller, H \& Wattenburg, MP 1984, 'Politics from the pulpit: religiosity and the 1980 elections', The Public Opinion Quarterly, vol.48, no.1, pp.301-317.

Miller, L 2010, 'The Newsweek 50: E. A. Adeboye', Newsweek, 19 December. Available at: <http://www.newsweek.com/newsweek-50-e-adeboye-83039> (20 September 2015)

Norris, P \& Inglehart, R 2004, Sacred and secular: religion and politics worldwide, Cambridge University Press, Cambridge.

Nzemeke, V 2014, 'President Jonathan's church tourism', Real Magazine, 17 March. Available at: <http:/ / realnewsmagazine.net/ politics / president-jonathanschurch-tourism /> (15 September 2015).

Obadare, E 2006, 'Pentecostal Presidency? The Lagos-Ibadan "theocratic class" \& the Muslim "other"', Review of African Political Economy, vol. 33, no. 110, pp. 665-678.

Oloyede, IO 1987, 'The council of Muslim youth organizations of Oyo state in Nigeria: origins and objectives', Journal Institute of Muslim Minority Affairs, vol. 8, no. 2, pp. 378-386.

Onapajo, H 2015, 'Nigeria's 2015 general elections: The salience of electoral reforms', The Round Table, vol. 104, no. 5, pp. 573-584.

Onapajo, H\& Usman, AA2015, 'Fuelling the flames: Boko Haram and deteriorating Christian-Muslim relations in Nigeria', Journal of Muslim Minority Affairs vol.35, no.1, pp.106-122.

Onapajo, H 2012, 'Politics for God: religion, politics, and conflict in democratic Nigeria', Journal of Pan African Studies, vol. 4, no. 9, pp. 42-66.

Osaghae, EE 1998, Crippled giant: Nigeria since independence, Indiana University Press, Bloomington, Indiana.

Philpott, D 2002, 'The challenge of September 11 to secularism in international relations', World Politics, vol. 55, pp. 66-95.

Premium Times 2015, 'Buhari meets Catholic Bishops, allays fears on religious freedom' 11 February. Available at:<http:/ / www.premiumtimesng.com/ news / top-news / 176630-buhari-meets-catholic-bishops-allays-fearsreligious-freedom.html $>$ (21 September, 2015).

Premium Times 2014, 'Jonathan meets Sultan of Sokoto, others; denies deliberate marginalisation of Muslims' 26 March. Available at: <http://www. premiumtimesng.com/national-conference/jonathan-meets-sultansokoto-others-denies-deliberately-marginalisation-muslims> September 2015)

Ross, W 2015, 'Nigeria elections: mixing religion and politics'. Available at: < http: / / www.bbc.com/news/world-africa-31026554> (14 September 2015).

Rufai, SA 2011, 'The mosque and the state house: political Islam in contemporary Nigeria since 1999', World Journal of Islamic History and Civilization, vol. 1, no. 3, pp. 178-186. 
Sahara Reporters 2015, “"Osinbajo is my problem"- President Jonathan cries out in secret meeting with Pentecostal pastors in Abuja' 19 January. Available at: $\quad$ http:/ / saharareporters.com/2015/01/19/\%E2\%80\%9Cosinbajomy-problem\%E2\%80\%9D-president-jonathan-cries-out-secret-meetingpentecostal-pastors> (16 September 2015).

Suberu, R 1997, 'Religion and politics: A view from the south', in L Diamond, A Kirk-Greene, and O Oyediran (eds.). Transition without end: Nigerian politics and civil society under Babangida. Lynne Rienner, Boulder, Colo.

Umoru, H 2015, 'We're not responsible for your loss, PDP tells GEJ', Vanguard, 5 May. Available at: <http:/ / www.vanguardngr.com/2015/05/were-notresponsible-for-your-loss-pdp-tells-gej/> (10 January 2016).

Umoru, H \& Akinrefon, D 2015, 'PDP, APC in 'war of words' over use of religion', Vanguard 9 January. Available at: <http://www.vanguardngr. com/2014/01/pdp-apc-war-words-use-religion/> (30 September 2015).

Van der Brug, WB, Hobolt, S \& De Vreese, CH 2009, 'Religion and party choice in Europe', West European Politics, vol. 32, no. 6, pp. 1266-1283.

Theodorou, AE, 2015, 'Americans are in the middle of the pack globally when it comes to importance of religion', Pew Research Center, 23 December 2015. Available at: <http: / / www.pewresearch.org/fact-tank/2015/12/23/ americans-are-in-the-middle-of-the-pack-globally-when-it-comes-toimportance-of-religion / > (15 January 2016).

Top News 2014, 'Sule Lamido lambasts Buhari: "Your campaign is divisive and false".' Available at: <http://www.topnewsmagazines.com/gov-sulelamido-lambasts-buhari-your-campaign-is-divisive-and-false / > September 2015).

Vanguard 2012, '2015'll be bloody if...- Buhari', 15 May. Available at: http: / / www. vanguardngr.com/2012/05/2015-11-be-bloody-if-buhari/ (5 October 2015). Vanguard 2014, 'APC is the political wing of Boko Haram- Fani-Kayode' 6 August. Available at: <http://www.vanguardngr.com/2014/08/apcpolitical-wing-boko-haram-fani-kayode/> (10 October 2015).

Yisa, J 2015, “"Keep your dollars": South West Muslim leaders snub Jonathan.' The News, 2 March. Available at: <http://thenewsnigeria.com.ng/2015/03/ keep-your-dollars-south-west-muslim-leaders-snub-jonathan / > October 2015). 